\title{
LENDIR BEKICOT MENINGKATKAN JUMLAH SEL MAKROFAG PADA PENYEMBUHAN LUKA PASCA PENCABUTAN GIGI MARMUT
}

\author{
Putu Sulistiawati Dewi, Setiawan DS \\ ${ }^{1,2}$ Department of Oral and Maxillofacial Surgery, Faculty of Dentistry, \\ University of Mahasaraswati Denpasar, Bali \\ Email: p_liez@yahoo.com
}

\begin{abstract}
Tooth extraction is a common practice in dentistry. Tooth extraction will cause injuries that need healing before they can return to the physiological state of the oral cavity. Snail mucus contains beta agglutinin (antibodies) in plasma (serum), achasin protein, glycoconjugate and sulfate levels which can accelerate wound healing by increasing the mobilization of macrophage cells on day 5 after tooth extraction. The purpose of this study was to determine the effectiveness of snail mucus on the number of macrophage cells in wound healing after extraction of guinea pigs. The research method used was pure experimental research using 32 guinea pigs as samples. Guinea pigs were divided into 2 (two) groups: the control group was given $2 \% \mathrm{CMC}-\mathrm{Na}$ gel and the treatment group was given snail mucus after having been extracted. Calculation of the number of macrophages is done on the 5 th day. The results showed the mean number of macrophage cells in the control group was 13.06 cells, and the treatment group was 17.44 cells. After being analyzed using the Independent t-test with significance $\rho<0.05$, it was found that there were significant differences in the number of macrophage cells in the test group and the control group. From this study it can be concluded that snail mucus is effective in increasing the number of macrophage cells in the process of wound healing after tooth extraction.
\end{abstract}

Keywords : snail mucus, macrophage cell, tooth extraction

\section{PENDAHULUAN}

Pencabutan gigi yang ideal adalah pencabutan sebuah gigi atau akar gigi yang utuh tanpa menimbulkan rasa sakit dengan trauma sekecil mungkin pada jaringan penyangganya sehingga bekas pencabutan akan sembuh secara normal. Jika luka bekas pencabutan gigi tidak ditangani dengan baik maka akan menimbulkan komplikasi. ${ }^{1}$ Pada saat terjadi luka, secara fisiologis akan diikuti dengan adanya suatu proses penyembuhan luka. Jaringan yang rusak akibat terjadinya luka akan direspon oleh tubuh melalui respon vaskuler dan seluler, sehingga terjadi proses penyembuhan luka. Tubuh akan menyempurnakan proses penyembuhan dengan pembentukan jaringan baru menjadi jaringan penyembuhan yang kuat dan bermutu. $^{2}$

Proses penyembuhan luka terdiri dari 4 fase, yaitu: fase hemostatis, fase inflamasi, fase proliferasi, dan fase maturasi. Pada fase Inflamasi terjadi proses vasokonstriksi, pengerutan ujung pembuluh darah yang putus (retraksi), dan reaksi hemostasis. Jika fase inflamasi berlangsung berlarut-larut, ini akan sangat menghambat proses penyembuhan luka karena fase prolifeasi baru bisa dimulai jika fase inflamasi sudah berakhir dimana jaringan luka sudah terbebas dari komponen jaringan yang rusak, mikroorganisme, serta sel-sel host yang sudah tidak berfungsi lagi. ${ }^{3}$

Makrofag dan mononuklear leukosit lain merupakan sel yang berperan pada fase inflamasi. Makrofag berfungsi mempertahankan jaringan normal dengan memakan sel mati, debris sel, dan benda renik lain kemudian memecah sel-sel tersebut dengan enzim lisosom. ${ }^{4}$ Makrofag muncul 24 jam setelah terjadinya luka untuk menggantikan neutrofil dan akan menjadi dominan pada jaringan luka setelah hari ke-5. Selain fagosistosis makrofag juga merupakan sel utama yang mensekresi sitokin. Mediator ini sangat penting untuk fase penyembuhan luka selanjutnya, karena mempengaruhi diferensiasi dan dapat membantu membangun kembali jaringan yang rusak. Berakhirnya fase inflamasi ditandai dengan menurunnya jumlah makrofag. 5

Saat ini kecenderungan masyarakat untuk menggunakan pengobatan tradisional semakin tinggi, sehingga pemanfaatan bahan-bahan alamiah cenderung meningkat, termasuk beberapa jenis tumbuhan dan hewan yang digunakan sebagai obat-obatan tradisional. Salah satunya dengan menggunakan lendir bekicot (Achatina fulica). ${ }^{6}$ Dalam masyarakat daging bekicot dan lendirnya sangat bermanfaat untuk mengobati berbagai macam penyakit seperti abortus, sakit waktu menstruasi, radang selaput mata, sakit gigi, gatal-gatal, sakit jantung, penyakit kulit dan luka ringan.

Penyembuhan dengan lendir bekicot menjadi salah satu alternatif karena mudah dalam penggunaan, daya sebarnya pada kulit baik, tidak menyumbat poripori kulit, juga memiliki efek anti bakteri. ${ }^{8}$ Lendir bekicot memberikan reaksi positif terhadap pengujian kandungan protein yang berperan regenerasi sel dan pertumbuhan, diantaranya adalah asam amino dan enzim. Protein dapat berfungsi dan berperan dalam pertumbuhan, pertahanan, fungsi tubuh dan sebagai fungsi protektif yaitu pengganti jaringan dan sel yang rusak. Berdasarkan dari fungsi protein ini diperkirakan kandungan protein hewani pada lendir bekicot mempunyai nilai biologis yang tinggi, yaitu dalam penyembuhan dan penghambatan proses inflamasi. ${ }^{9,10}$ Tujuan Penelitian ini adalah untuk mengetahui efektifitas lendir bekicot (Achatina fulica) terhadap peningkatan jumlah sel makrofag pada penyembuhan luka pasca ekstraksi gigi marmut (Cavia cobaya). 


\section{BAHAN DAN METODE}

Pada penelitian ini beberapa alat yang digunakan antara lain: mikroskop elektrik (Olympus Type CX21), skalpel nomor 10 dan handle, pisau cukur dan gagangnya, gunting bedah, pinset, toples, cotton bud dan syringe. Bahan yang digunakan antara lain: lendir bekicot, bahan pengecatan: Hematoksilin Eosin (HE), anastesi (ketamine + xylazine) dan aquades. Perlakuan pada marmut dan proses pengambilan jaringan dilakukan di Laboratorium Fakultas Kedokteran Hewan, Universitas Udayana Denpasar. Proses pemerikasaan secara histologis seperti pembuatan blok paraffin, preparat, pewarnaan sampai pembacaan hasil dilakukan di Laboratorium Histologi, Fakultas Kedokteran Universitas Udayana Denpasar. Jenis penelitian ini adalah penelitian eksperimental laboratoris, menggunakan marmut (Cavia cobaya) sebagai sampel sebanyak 32 ekor dengan kriteria yaitu marmut jantan berusia 2-3 bulan dengan berat 200-300 gram. Marmut diadaptasikan selama seminggu di dalam kandang yang cukup aliran udara dan cahaya serta diberi makanan dan minuman. Sampel diambil secara random dan dibagi menjadi 2 kelompok.

Marmut kemudian dianastesi dengan menggunakan ketamin yang dikombinasikan dengan xylazine dengan dosis ketamin $40 \mathrm{mg} / \mathrm{kg}$ BB dan xylazine $5 \mathrm{mg} / \mathrm{kg}$ BB secara intramuscular, kemudian dilakukan pencabutan gigi insisivus kiri rahang bawah menggunakan alat modifikasi tang dan elevator, pencabutan dilakukan dengan hati-hati agar akar gigi tidak fraktur dan gigi tercabut sempurna, kemudian soket gigi diirigasi dengan larutan aquades steril. Pada kelompok perlakuan, soket yang telah diirigasi diberikan lendir bekicot dengan cara diteteskan menggunakan syringe sampai soket terisi penuh $\pm 0,1$ ml. Pemberian lendir bekicot dilakukan 3 kali sehari setelah pencabutan,selama 5 hari. Pada hari ke 5, marmut didekapitasi dengan chloroform, kemudian dilakukan pengambilan specimen di daerah luka yaitu bagian soket gigi rahang bawah marmut, selanjutnya jaringan difiksasi dengan buffer formalin $10 \%$ dan dibuat sediaan mikroskopik. Untuk semua specimen, pemotongan dengan mikrotom dilakukan dengan ketebalan 5 mikron, lalu diwarnai dengan Hematoksilin Eosin (HE). Pemeriksaan histopatologi dilakukan pada $1 / 3$ apikal soket dengan pembesaran 400x pada 3 lapang pandang kemudian dihitung jumlah sel makrofag. Hasil perhitungan diambil rata-ratanya dan dilakukan analisis data.

\section{HASIL PENELITIAN}

Data jumlah sel makrofag pada setiap kelompok diuji normalitasnya dengan menggunakan uji Kolmogorov-Smirnov. Hasilnya menunjukkan bahwa data jumlah sel makrofag berdistribusi normal ( $>$ >0,05), disajikan pada Tabel 1 .
Tabel 1

Hasil Uji Normalitas Data Jumlah Sel Makrofag pada setiap Kelompok

\begin{tabular}{cccc}
\hline $\begin{array}{c}\text { Kelompok Perlakuan } \\
\text { terhadap Sel Makrofag }\end{array}$ & N & P & Keterangan \\
\hline Kontrol (CMC-Na 2\%) & 16 & 200 & Normal \\
Lendir Bekicot & 16 & 200 & Normal \\
\hline
\end{tabular}

Kemudian data jumlah sel makrofag diuji homogenitasnya dengan menggunakan Levene's test. Hasilnya menunjukkan data homogen ( $>0,05)$, disajikan pada Tabel 2.

Tabel 2

Hasil Uji Homogenitas antar Kelompok Data Jumlah Sel Makrofag

\begin{tabular}{cccc}
\multicolumn{4}{c}{ Jumlah Sel Makrofag } \\
\hline Variabel & $\mathbf{F}$ & $\mathbf{p}$ & Keterangan \\
\hline Makrofag & 3.033 & 0.092 & Homogen \\
\hline
\end{tabular}

Analisis efek perlakuan diuji berdasarkan rerata jumlah sel makrofag antar kelompok sesudah diberikan perlakuan berupa pemberian lendir bekicot. Hasil analisis kemaknaan dengan Uji Independent t-test disajikan pada Tabel 3.

Tabel 3

Uji Perbedaan Rerata Jumlah Sel Makrofag Antar Kelompok Setelah Diberikan Lendir Bekicot

\begin{tabular}{lccccc}
\hline \multicolumn{1}{c}{ Kelompok Subjek } & $\mathbf{n}$ & $\begin{array}{c}\text { Rerata Jum lah } \\
\text { Sel Makrofag }\end{array}$ & SB & F & P \\
\hline Kontrol (CMC Na 2\%) & 16 & 13.06 & 4.79 & 4.375 & 0.039 \\
Lendir Bekicot & 16 & 17.44 & 6.54 & & \\
\hline
\end{tabular}

Tabel 3 menunjukkan bahwa rerata jumlah sel makrofag kelompok kontrol (CMC-Na 2\%) adalah $13.06 \mathrm{sel}$, rerata kelompok lendir bekicot adalah 17.44 sel. Analisis kemaknaan dengan uji Independent t-test menunjukkan bahwa nilai $F=4.375$ dan nilai $\mathrm{p}=$ 0.039 , hal ini menunjukkan bahwa rerata jumlah sel makrofag pada kedua kelompok setelah diberikan perlakuan berbeda bermakna $(\mathrm{p}<0,05)$. Hasil analisis menyimpulkan bahwa lendir bekicot lebih efektif dalam meningkatkan jumlah sel makrofag pada proses penyembuhan luka pasca pencabutan gigi marmut.

\section{PEMBAHASAN}

Uji perbandingan kedua kelompok setelah perlakuan menggunakan uji Independent t-test didapatkan rerata jumlah makrofag pada kelompok CMC-Na $2 \%$ adalah 13.06, kelompok lendir bekicot adalah 17.44 dengan $F=4.375$ dan $\rho=0.039$. Hal ini menunjukkan bahwa rerata jumlah makrofag pada tiap kelompok berbeda secara bermakna $(\rho<0,05)$.

Peningkatan jumlah makrofag pada penyembuhan luka pasca pencabutan gigi marmut diduga disebabkan karena beberapa sifat lendir bekicot yaitu mengandung zat beta aglutinin (antibodi) di dalam plasma (serum), protein achasin, glikokonjugat dan acharan sulfat yang berperan dalam proses penyembuhan luka dengan membantu proses pembekuan darah dan proliferasi sel makrofag. ${ }^{8}$ 
Achatina fulica diketahui dapat membuat bactericidal glycoprotein yang ditemukan pada lendir yang bersifat melindungi dan mengandung heparin yang berfungsi sebagai antibakteri. Lendir bekicot dapat meningkatkan tingkat migrasi sel makrofag yang berperan penting dalam proses perbaikan jaringan luka. ${ }^{11}$

Lendir bekicot mengandung glikokonjugat kompleks, yaitu glikosaminoglikan dan peptidoglikan. Molekul tersebut terutama disusun dari gula sulfat atau karbohidrat, protein globuler terlarut, asam urat dan oligoelemen (tembaga, seng, kalsium, dan besi). Glikosaminoglikan yang terisolasi dari bekicot terkait dengan golongan heparin dan heparin sulfat. Glikosaminoglikan dan proteoglikan merupakan pengontrol aktif fungsi sel, berperan pada interaksi matriks sel, proliferasi fibroblas, spesialisasi, dan migrasi serta secara efektif mengontrol fenotip seluler. Glikokonjugat utama pada lendir bekicot yaitu glikosaminoglikan disekresi oleh granula yang terdapat didalam tubuh bekicot dan terletak dipermukaan luar. Lendir bekicot juga mengikat kation divales seperti tembaga (II) yang dapat mempercepat proses angiogenesis yang secara tidak langsung mempengaruhi kecepatan penyembuhan luka. ${ }^{11}$

Dalam proses penyembuhan luka makrofag berperan dalam mempertahankan jaringan normal dengan memakan sel mati. debris sel dan benda renik lain sekaligus memecahnya dengan enzim lisosom (fagositosis). Mereka juga merupakan garis pertahanan pertama terhadap infeksi, dengan cara menghancurkan bakteri yang masuk, selain itu makrofag merupakan partisipan yang harus ada dalam pertahanan imunologis tubuh dengan memproses dan menyajikan antigen pada limfosit yang mampu menghasilkan antibodi protektif. ${ }^{4}$ Jadi dapat disimpulkan bahwa semakin banyak jumlah makrofag pada suatu jaringan luka akan mempercepat proses penyembuhan luka terutama pada fase inflamasi.

Sel makrofag yang telah teraktivasi menghasilkan peningkatan aktivitas metabolik dan menstimulasi sekresi growth factor (transforming growth factor $\beta$ [TGF- $\beta$ ], sitokin IL-12, IL-6, dan IL23. Mediator ini sangan penting untuk fase penyembuhan luka selanjutnya yaitu mempengaruhi rekrutmen dan diferensiasi sel dan menjadi awal dalam pembentukan kembali jaringan yang rusak. Makrofag adalah sumber utama sitokin yang berpengaruh dalam kemostasis limfosit dan selanjutnya merupakan bagian yang penting pada proses penyembuhan luka. TGF- $\beta$ secara khusus menstimulasi fibroblast untuk berpoliferasi dan mensintesis matriks protein ekstraseluler. Pada proses penyembuhan luka fase inflamasi, absen atau sedikitnya jumlah sel makrofag akan menyebabkan fibroblast sedikit yang terstimulasi, hal ini akan menyebabkan proses penyembuhan menjadi lebih lambat. ${ }^{5}$

\section{SIMPULAN}

Lendir bekicot (Achatina fulica) efektif meningkatkan jumlah sel makrofag pada proses penyembuhan luka pasca pencabutan gigi marmut (Cavia cobaya).

\section{UCAPAN TERIMA KASIH}

Terimakasih kepada pihak Fakultas Kedokteran (laboratorium histologi) dan Fakultas Kedokteran Hewan, Universitas Udayana Denpasar serta kepada mahasiswa Fakultas Kedokteran Gigi, Universitas Mahasaraswati Denpasar: Pradnyana Iswara yang telah membantu penelitian ini.

\section{DAFTAR PUSTAKA}

1. Maryunani A. Perawatan Luka Modern (Modern Woundcare) Terkini dan Terlengkap, In Media. 2015.Jakarta.

2. Sugiaman VK. Peningkatan penyembuhan luka di mukosa oral melalui pemberian Aloe Vera (Linn.) secara topikal. JMK; 2011: 11 (1); p 72-3: [internet]. Available from http:// majour. maranatha. edu/index. php/ jurnalkedokteran/ article/ download / 907/ pdf.

3. Sjamsuhidajat $\mathrm{R}$ dan Wim de Jong. Buku Ajar Ilmu Bedah. 2010. Edisi 3. EGC. Jakarta

4. Fawcett, Don W. Buku ajar histology, edisi 12,Penerjemah :Tambayong J. Penerbit Buku Kedokteran EGC. 2009. Jakarta.

5. Nanci,A. Ten Cate's Oral Histology : development, structure, and function. Amsterdam : Mosby Elsevier Fawcet, DW (2002). Buku ajar histology. 2008. EGC. Jakarta.

6. Muhartanto, Sibero H T dan Jaya B P. Snail Slime as Alternative Hydrogel for Healing Burns Woud on Rats. 2014. Unila Research Article. 144-150

7. Berniyanti T, Suwarno. Karakteristik Protein Lendir Bekicot (Achasin) Isolat Lokal sebagai Faktor Anti Bakteri. Media Kedokteran Hewan. 2007;23(3):139-44.

8. Purnasari PW, Fatmawati D, Yusuf I. Pengaruh Lendir Bekicot (Achatina fulica) terhadap Jumlah Sel Fibroblas pada Penyembuhan Luka Sayat. Sains Medika; 2012;4(2):195-203.

9. Berniyati T, Edy B W dan Suwarno. Biochemical Characterization. Of an Antibacterial Glycoprotein from Achatina fulica ferussac snail mucus local isolate and their implication on bacterial dental infection. 2007. Indonesia Journal of Biotechnology. 12(1): 944

10. Adikwu M U dan Okafor J O. Application of the animal products mucin and honey in wound healing: a pathophysiology, therapeutics and Pharmaceutical review. 2012. AJPSP. 3(2): 3-8

11. Kim, Y.S., Jo, Y.Y., Chang, I.M., Toida, T.,Park, Y.M.,Linhardt, R.J., A New Glycosaminoglycan from the Giant African Snail Achatina fulica. J. Biol. Chem.271, 1996. 11750-11755 